IKONOMIKA: Journal of Islamic Economics and Business

Volume 3, No I (2018)

ISSN : 2527-3434 (PRINT) - ISSN: 2527-5I43 (ONLINE)

Page : $17-34$

\title{
IFRS Based Zakat Reporting: Adoption Rational Western Method Into Institutional Accountability
}

\author{
Mohammad Bintang Pamuncak ${ }^{1}$, Bayu Taufiq Possumah ${ }^{2}$, \\ Zairihan Abdul Halim ${ }^{3}$ \\ Universiti Malaysia Terengganu (UMT) ${ }^{1,2,3}$ \\ bayu@umt.edu.my²
}

\begin{abstract}
This study aims to evaluate the characteristics of zakat institution and proposes the adoption of International Financial Reporting Standard (IFRS) since it has developed and provides various product i.e zakat for productive purpose. This is important, considering that one of the measurement of accountability and transparency of an institution is providing brief financial report towards its beneficaries. Thereby, this study found that practically zakat institution is simillar to the SMEs, and there are II strandard of IFRS for SMEs that could be applicable to zakat institutionto achieve accountability and transparency. However, this study is preliminary study that proposes a conceptual frameworkwhich limited to the sharia compliance of IFRS that could be applicable to zakat Institution.
\end{abstract}

Keywords: IFRS for SMEs, SMEs Criteria, Zakat Institution JEL Classification:

\section{A. INTRODUCTION}

By today, we can see the massive development of zakat institution, proven by the growing of zakat fund that had collected by zakat Institution accross the globe. For example, several studies such (Al Parisi;2017) and Puskas BAZNAS forcasted that in the 2029 the zakat fund could be collected in Indonesia is 8.33 IDR trillion. It is a huge amount comparing with the zakat collection in 2015 which is only reach 3.7 IDR trillion. However, the potential of zakat fund collection in 2015 itself reach 286 IDR trillion, means the realization of zakat fund collection is not even close with the target. It is because the zakat fund collecting system is voluntary in Indonesia. The more amount of zakat would be collected if the zakat is mandatory by the government.

Received :May 06, 2018- Revised: May I0, 2018- Accepted :May 23, 2018

Universiti Malaysia Terengganu (UMT) ${ }^{1,2,3}$

E-mail: bayu@umt.edu.my ${ }^{2}$ 
Ifrs Based Zakat Reporting: Adoption Rational Westernmethod Into

Institutional Accountability

(Mohammad Bintang Pamuncak ${ }^{1}$, Bayu Taufiq Possumah², Zairihan Abdul Hamid ${ }^{3}$ )

Furthermore, the indicator that could be used as a measurement of the development of zakat institution is how far the zakat institution be beneficial toward its beneficaries. (Hassan and Noor;20I5) empirically proved that Capital based zakat fund assistance particulary for retail and manufacturing business that had been done by Selangor Zakat Board (SZB) Malaysia could really help the poor. Moreover, another study discovers that the zakat and waqf fund support lowincome household becomes better in social securities and socio economic (Mikail; et.a12017)

Those two studies are evidences of successfull application of zakat fund based Islamic Microfinance institution (Ahmed;2002, Rahman and Dean, 20I3, Kaleem et.al;2010). While other study also reveals that the zakat fund had been use through Islamic finance scheme in Indoensian Zakat Institution, and lately known as Zakat for Productive purpose (Yumna and Clarke, undate). This mean, that practically the zakat institution in some countries, such Indonesia and Malaysia had already utilize the zakat fund for productive purpose using Microfinance and Small and Medium Enterprises (SMEs) approach.

However, zakat institution also comes up with some problems, one of it is about the financial accounting standard. As in Indonesia, the financial accounting standard for zakat institution is regulated by the Indonesian Accounting Council (IAI) in the National Accounting Standard (PSAK) for Sharia no I09 about zakat infaq and shadaqa. (Alim;20I5) criticized that the application of zakat for productive purpose, which is using the qard hasan (loan) is not permissible in Islam. Therefore, (Alim;2015) suggests that PSAK I09 must be reviewed from fiqh perspectives and IAI must developed the new mechanism and financial reporting for zakat for productive purpose that compatible with fiqh issues.

Beside that, just like the waqf institution, the characteristic of zakat institution, which is a nonprofit and charitable organization, required the institution to apply good corporate governance. The basic principles of good governance which taken from Islamic Values are amanah, adalah and syuro. The application of those values then requires the institution to perform sharia audit, financial audit and etc. (Ihsan and Ayedh;2015) This is important and consider as one of the consequences of Tauhid,i.e the accountability to Allah and mankind (including beneficaries and stakeholders) (Saad, et.al, 20I4; Ihsan and Ayedh; 2015)

In order to maintain the accountability and efficiency of zakat institution, other study discusses about the accountability and efficiency practices of charitable organization. For instance (Abd Wahab and Abdul Rahman;20II) disscussed 
about the efficiency of Zakat institution using United Nation Development Program (UNDP) good governance standard. They found that Thenical Effiecncy, such Board size and proprtion of professionals on board would lead to Zakat Institution efficiency. Other elements are Pure Technical Efficiency (PTE) and Scale Efficiency would also lead the institution be more efficient.

(Furthermore Yacoob, et.al;20I5) disscussed about the successfull story of Waqf $(S)$ institution, which the institution of Waqf in one of the Southeast Asia non Muslim majority country. They argue that the Waqf (S) institution performance is successfull considering to the good management, accounting nd reporting of financial activities of the institution. In addition, they argue that the Waqf $(S)$ institution successfull story is driven by regulatory (form government), stakeholders demands and religious image.

From the explanation above, we can know that the development of zakat institution in Indonesia is massive. However, zakat institution in Indonesia also needs an evaluation and suggestion, particularly in the term of financial reporting standard that still have figh issues, particularly in the reporting of zakat for productive purpose. This is important, considering that the financial reporting of zakat institution is a meausrement of good governance of the institution. Whereas the financial reporting is a measuerement of accountability and transparency of an institution.

\section{B. THEORITICAL}

Therefore, this study attempts to evaluate the characteristics of zakat institution and compare it with the characteristics of Islamic Microfinace Institution and Characteristics of Small and Medium Enterprises (SMEs) in Indonesia, so then the International Financial Reporting Standard (IFRS) which is a financial standard that accept globally can be used as a main reference for evaluating the PSAK 109 about zakat infaq and shadaqa. Nevertheless, there is also an Accounting and Audit Organizations for Islamic Financial Institution (AAOIFI) Standard, a standard that also used globally for Islamic Financial Institution (IFI). However, as it was stated before that zakat Institution had practically utilize the zakat fund using Islamic Microfinance channel and SMEs approach, we assume that the zakat institution inderectly labelled as Islamic Microfinance Institution. Therefore, the standar that we use as a main reference in this study is IFRS for SMEs Standard. Since it is also known that AAOIFI had no standard for smaller entities (AOSSG;2015) 
Ifrs Based Zakat Reporting: Adoption Rational Westernmethod Into

Institutional Accountability

(Mohammad Bintang Pamuncak ${ }^{1}$, Bayu Taufiq Possumah², Zairihan Abdul Hamid ${ }^{3}$ )

\section{Ifrs Framework: An Inplementation Judgement}

One of the main reason why we need the financial reporting standard that has a compliance with IFRS for zakat institution is related to the environment of big companies across the globe whom already applied the financial reporting standard that have a compliance with IFRS. It is because when a company went global, it need a financial standard that accepted globally. With this standard unification, it makes those companies easier to be compared each to another. Furthermore, as a consequence, the companies who have similar standard then issued a financial reporting standard that can be tested, more understandable, neutral, issued on time, competitive and comprehensive. Until now, there are several countries who have already issued financial reporting that has a compliance with IFRS, those are: Korea, India and Canada which already started at 201I. Therefore, Indonesian Accounting Council (IAI) the institution that issues National Accounting Standard (PSAK) made IFRS as a standard for financial reporting in Indonesia since 2012 (Siaran Pers Ikatan Akuntan Indonesia, 24 December 2008)

Another reason why we need IFRS as reporting standard is because the IFRS compliance of financial reporting standard in some countries has been adapted rapidly and it gives more benefits than before for some companies, particularly in improving transparency. Therefore, this reason encourage zakat institutions in Indonesia to apply financial reporting standard which complies to the IFRS in order to improve their transparency and linearly can be compared and compete to other institution (profit or non-profit oriented) particularly in financial performance. This means, IFRS can be used as main reference of financial reporting standard for zakat institution in Indonesia. It is because as it was stated before, that the IFRS is financial reporting standard that has been used globally, whereas it is drafted by many distinguished accounting scholars across the globe. Nevertheless, the compatibility of IFRS and National Accounting Standard (PSAK) in Indonesia is another study that can be explored further.

The uniqueness of financial reporting with Sharia touch especially for Zakat Institutions is that financial reporting must always complies with sharia objectives not just provides useful information for decision makers In this case, IFRS might help to achieve Sharia objective in several ways. For example, establishing good disclosure guidance, contributing to increasing the disclosure level, and providing moretransparency (Alkhtani;20I2). This is very much what the Sharia committee needs. Which is full disclosure in financialstatements that will increase accuracy of the reported Zakat amount and preserve social accountability(Al Suhaibani;20I2). 
Since IFRS requires the use of fair value for fixed assets and liabilities, Zakat reporting standard will be able tomake better decisions since financial statements across companies in different countries will be using the samemethod with regards to valuing assets and liabilities (Alkhtani;20I2). Since the market like Indonesia is still a developing, this is an important matter in relation toZakat Institution to achieve fair value calculations. This issue is exacerbated by the fact that there currently is no regulatory body to enforce valuations in theIndonesian market. As this relates to the calculation of Zakat, the end result could be inaccurate calculations by theZakat institution (Alkhtani).

From Sharia perspectives, using fair value as applied in IFRS could be more accurate and favourable rather than using the historical cost thattraditional financial reporting which have previously used. The use of historical cost data in assessingbusiness zakat is inappropriate for zakat purposes especially in the time of rising prices. This isdue to the fact that zakat distribution to its beneficiaries would be undervalued during inflation. Hence, fairnessand equitable, which is promoted by Islam may be impaired" (Awang and Mokhtar;20I2). Consequently, IFRSmay better serve Sharia goals more than traditional financial reporting or it is likely to be considered the same.

Furthermore, the main issue associated with the Zakat Standard relates to the absence of regulation that considers the underlying purpose of Zakat under the tenets of Islam and how Zakat should be classified on financial statements. The current standard only focuses on how to present accounting information and how todisclose this information without really considering the calculation or the source of Zakat (Alkhtani;2010).

\section{Ifrs Based Zakat Reporting: The Adoption Process}

Indonesia is a country that ruled in a code law (Code law is also known by civil law which is inspired by roman law. It is also known written on a paper or draft which is simplified the law in a code. Principally, the colde law is a law that can accessed by all elements of society therefore society can know the law that ruled out in their life. This kind of law has been used by almost I50 countries around the world nowadays. Moreover, this law is initiated by Napoleon bonaparte when he ruled out Europe and netherland brings this method to Indonesia as they colonialized Indoneisa for over 350 years) whereas the financial reporting issuance is supposed to be issued with 'proper' rate and not for discovering the truth. Moreover, The level of convergence of IFRS to national accounting standard (PSAK) in Indonesia is not fully implemented, whereby some standard such as depreciation, standard for determining the financial loss, leases, and tax is not 
Ifrs Based Zakat Reporting: Adoption Rational Westernmethod Into

Institutional Accountability

(Mohammad Bintang Pamuncak ${ }^{1}$, Bayu Taufiq Possumah², Zairihan Abdul Hamid ${ }^{3}$ )

included in the national standard. It is because those standard beleived would be counterproductive with the national law.

Therefore, understanding the process of IFRS adoption in developing economies is crucial because the process through which IFRS are adopted significantly influences the relevance and importance of IFRS in these countries (Mir \&Rahaman;2005 as cited in Maradona;2017). Refer to (Maradona and Chand;2017) there are five different convergence approaches a country can choose in adopting IFRS, namely:

a. full adoption of IFRS;

b. ii)selective adoption of IFRS or adoption with a time lag;

c. IFRS adoption with modification to account for country-specific characteristics;

d. preservation of national accounting standards but in harmony with IFRS; and

e. continuation of national accounting standards (Chand \& Patel, 20I I p.I5).

This also supported by Media Akuntansi (2005) as quoted by Immanuela (2009) who discovers that there are five levels of convergence, those are: a) full adoption, b) adapted, c) peacemeal, d) referenced and e) not adoption at all. Furthermore, Immanuela (2009) stated that there are several problems with the step of financial reporting standard adoption in some countries, particularly Indonesia, so that the level of financial reporting standard adoption is various.

While basically, the problem of covergence is begin with the bad interpretation from the IFRS. The IFRS is issued by IASB in english, so that sometimes there is an inconsistency between the IFRS and new standard, particularly between the concept and its aplication in some countries, for example, Indonesia. Furthermore, the obstacle that makes the IFRS can not fully adopted is that sometimes there is a lag between IFRS and national law in some countries, so that the IFRS must be transformed by the national accounting council of each countries. (Immanuela;2009)

Highlighting the issues, there are several things need to ponderin process to adopt the IFRS standard to zakat institution:

\section{Repositioning Role of Zakat Institution (As SMES)}

Zakat intitution is a charitable organization that responslible for providing services regarding zakat fund management (Abd Wahab, et.al, 20I7). They are also responsible to distribute the zakat fund for beneficaries (Abd. Wahab, et.al, 2017) and also reported the financial statement to the stakeholders as one of the indicator of good governance i.e accountability to Allah and beneficaries (Saad, et.al, 20I4; Ihsan and Ayedh, 2015) 
While according to Ayyagari et.al (2007) there is no similar term, definition or measurement of Small and Medium Enterprises (SMEs) due to the variance term, definition or measurement across the globe. However, the SMEs across the globe share similar characteristics that must included in the SMEs. Those are: a) number of employees, b) total net assets, c) sales and d) investement level

In the other hand, Ahmed (2002) stated that the Islamic Microfinance institution is an alternative of the failure of conventional microfinance institution. The Islamic Microfinance institution is a microentreprises finance institution that based on Islamic values. In addition, the Islamic Microfinance institution is totally different with the conventional microfinance institution. The differences between the two institution are in Liabilities source, Assest management, Financing scheme for the poor, target group and so on. This table below explains briefly the differences of those two institution

\begin{tabular}{|c|c|c|}
\hline & Conventional Mfi & Islamic Mfi \\
\hline Liabilities & $\begin{array}{l}\text { External funds, Saving of } \\
\text { clients }\end{array}$ & $\begin{array}{l}\text { External funds, Savings of } \\
\text { Clients, Islamic charitable } \\
\text { sources }\end{array}$ \\
\hline $\begin{array}{l}\text { Assets (mode of } \\
\text { financing) }\end{array}$ & Interest based & $\begin{array}{ll}\text { Islamic } & \text { financial } \\
\text { insturments } & \end{array}$ \\
\hline Financing the poor & Poorest are left out & $\begin{array}{l}\text { Poorest can included by } \\
\text { integrating zakat with } \\
\text { microfinancing }\end{array}$ \\
\hline Funds transfer & Cash given & Good transferred \\
\hline $\begin{array}{l}\text { Deductions at inception } \\
\text { of contract }\end{array}$ & $\begin{array}{l}\text { Part of the fund dedcuted } \\
\text { at inception }\end{array}$ & $\begin{array}{l}\text { No deductions at } \\
\text { inception }\end{array}$ \\
\hline Target group & Woman & Family \\
\hline Objetives of target group & Empowerment of woman & Ease of availability \\
\hline Liability of the loan & Recipient & Recipient and spouse \\
\hline $\begin{array}{l}\text { Work incentive of } \\
\text { employeses }\end{array}$ & Monetary & Monetary and religious \\
\hline Dealing with default & $\begin{array}{l}\text { Group/center pressure } \\
\text { and threats }\end{array}$ & $\begin{array}{l}\text { Group/center/spouse } \\
\text { guarantee and Islamic } \\
\text { ethics }\end{array}$ \\
\hline $\begin{array}{l}\text { Social development } \\
\text { program }\end{array}$ & Secular & Religious \\
\hline
\end{tabular}

Source: Ahmed, 2002 
Ifrs Based Zakat Reporting: Adoption Rational Westernmethod Into

Institutional Accountability

(Mohammad Bintang Pamuncak ${ }^{1}$, Bayu Taufiq Possumah², Zairihan Abdul Hamid ${ }^{3}$ )

As we discuss earlier about the characterics of SMEs, Islamic Microfinance and Zakat institution, we found that practically the zakat institution resembles the Islamic Microfinance characteristics through the zakat for productive program. Moreover, the zakat institution is also resembles the SMEs characteristic through the invesment and sales aspect. So here is the summary that contain the similarities of those institution:

\begin{tabular}{|c|c|c|}
\hline $\begin{array}{l}\text { Characteristics of SMEs } \\
\text { (Ayyagari, et.al, 2007) }\end{array}$ & $\begin{array}{ll}\text { Islamic } & \text { Microfinance } \\
\text { institution } & \end{array}$ & Zakat Institution \\
\hline Number of employees & Yes & Yes \\
\hline Total net assets & $\begin{array}{l}\text { Yes, mostly from client } \\
\text { savings and Islamic } \\
\text { charitable fund (Ahmed, } \\
\text { 2002) }\end{array}$ & $\begin{array}{l}\text { Yes, form zakat fund } \\
\text { which is an obligation in } \\
\text { Islam }\end{array}$ \\
\hline Sales & $\begin{array}{l}\text { Yes, using Islamic finance } \\
\text { schemes (Ahmed, 2002) }\end{array}$ & $\begin{array}{l}\text { Yes, using Islamic finance } \\
\text { Schemes }\end{array}$ \\
\hline Investment & $\begin{array}{l}\text { Yes, using Islamic finance } \\
\text { schemes (Ahmed, 2002) }\end{array}$ & $\begin{array}{l}\text { Yes, To the low income } \\
\text { level through zakat for } \\
\text { productive program } \\
\text { (Yuman and Clarke, no } \\
\text { year; Hassan and Noor, } \\
\text { 20I5) }\end{array}$ \\
\hline
\end{tabular}

Source:Author, processed

From the table above we argue that the zakat institution share the same characteristics with SMEs criteria on Number of employees, total net assets, sales and investment aspect. The characteristics then support the argument that practically zakat institution is similar to a SMEs organization. Hence, the performance of zakat institution can be measured also under IFRS standard.

4. Proposing IFRS for SME as based financial reporting standard for zakat institution

The IFRS for SMEs is issued by The International accounting standard board (IASB) at first in 2009. While The IASB itself was established in 200I in order to develop and set high quality of financial reporting standards based on clearly articulated principles. (IFRS for SMEs, 2015). However, at first IASB Issued IFRS for larger entities only. But later, IASB also issued IFRS for smaller entities in order to fulfill its own objective. Therefore, in 2009, IASB Issued IFRS for SMEs (IFRS for SMEs, 20I5) 
This issuance of the standard perhaps a reply from IASB after having some critics and suggests from some scholar about the financial reporting standard for smaller entities. One in particular is Fearnley and Hines (2007). The argue that non-listed entities in the United Kingdom are having trouble with the application of Full IFRS. Therfore they suggest to simplify the IFRS that later could be applicable to non-listed entites.

However, the IFRS for SMEs is not directly accepted by some countries. There are some challanges facing the IFRS for SMEs application. It because, Some scholar criticized the application of IFRS for SMEs and accussed that it is too complex for non-listed entitites. (Van Wyk and Rossouw, 2009; Francis and Agbeibor, 20I2). Van Wyk and Rossouw (2009) for instance stated that IFRS for SMEs is too complex to be applied in South Africa. It is because there is a scepticism among accountting practinioner whether the IFRS for SMEs could be the solution for the burden of financial reporting for SMEs. Moreover they also found that IFRS for SMEs is not deemed to be relevant for SMEs in Africa. Therefore, they suggest to IASB to accomodates and possibbly omitting the topics that related to the group statements

While Francis and Agbeibor (20I2) share the same opinion with Van Wyk and Rossouw (2009). They found that Small Business in Ghana have limited international structures and activites which result that IFRS for SMEs is not an appropriate accounting standard in Ghana. Therefore they future study to consider the perspective of SMEs's stakeholder, particularly in tax authorities and size categories of SMEs.

Moreover, study like Perera and Chand (20I5) and Mantzari, et.al (20I7) urge to modified and simplified the IFRS for SMEs. It it because, their study conclude that the IFRS for SMEs is not represented the accounting of SMEs in some countries. Mantzari et.al (2017) added that, the application of IFRS for SMEs by Greek non-listed entities is persued by the hegemony and pressure of Europe Commision. In fact, practitioner are not fully understand about the IFRS for SMEs.

Meanwhile, Perera and Chand (2015) also reveal that the adoption of IFRS for SMEs accross the globe is still a challange for small entities, especially micro entities. Some countries even modified and simplified the IFRS for SMEs to be more familiar with the small entities lately known as local standard. The local standar then used by small entites as financial statement of their business. In addition, they stated that the adoption from local standard to IFRS for SMEs 
Ifrs Based Zakat Reporting: Adoption Rational Westernmethod Into

Institutional Accountability

(Mohammad Bintang Pamuncak ${ }^{1}$, Bayu Taufiq Possumah², Zairihan Abdul Hamid ${ }^{3}$ )

would increase the cost of preparation for SMEs. The cost is associated with training, extra consultation and so on.

In the other hand, some studies is supporting the application of IRFS for SMEs (Masca, 2012; Uyar and Gungormus, 2013; Pacter, 20I4). Masca (2012) stated that the EU Commission considered the IFRS for SMEs is too complex, ivolved big cost and did not take the development of SMEs itself. However he found that those reason are only the justification to not apply the IFRS for SMEs. It is because, those reasons are influenced by the accounting culture and geographic area whic they are operate. Therefore, there is no problem with IFRS for SMEs strandard, but the problem is the practitionaries itself. And IFRS for SMEs is always challenging

Uyar and Gungormus (2013) share the same idea with Masca (2012). They found that the knowledge and perceptions of accountant regarding IFRS for SMEs in Turkey is low. It is because the practitioner in Tukey are lack of training programs that arranged by professional. Therefore, they are not highly informed the omission of certain topics in IFRS for SMEs.

Furthermore, Pacter (20I4) claims that the application of IFRS for SMEs will enhance the quality and comparibility of SMEs financial statements arround the world. It is also will conduct the SMEs to gain finance access to larger entities. This such practice is not only good for the institution, but also good for the beneficaries of the institution. Moreover, this such statement is also supported by the IASB as the institution that issued the IFRS for SMEs (IFRS for SMEs, 20I5)

The IFRS for SMEs consist of 35 standard. (IFRS for SME, 2015) And it is all the simplification of full IFRS standard in order to accomodates the SMEs criteria. However, not all the standard of IFRS for SMEs are applicable to the zakat institution. It is because some of the SMEs criteria such investment is not found in the Zakat institution criteria. Thereby, we classify the scope of IFRS for SME Standard that applicabe for zakat institution. And this table belows explain the simplification of IFRS for SMEs standard that applicable to the zakat institution.

IFRS for SMEs

Section Topic

I SMEs entities

Description: do not have accountability, publish general purpose financial statements for external users
Compatibility for Zakat Institution

Publish financial

statements for external users (stakeholders, zakat payers and beneficaries) 


\begin{tabular}{|c|c|c|}
\hline 2 & $\begin{array}{l}\text { Conncept and pervasive principles: Balance } \\
\text { between benefit and cost, in which push the } \\
\text { institution to determine the Financial } \\
\text { position, performance, Recognition and } \\
\text { measurement of Assets, liabilities, income } \\
\text { and expenses. }\end{array}$ & $\begin{array}{l}\text { Financial statment is } \\
\text { important for the } \\
\text { accountability of the } \\
\text { zakat institution }\end{array}$ \\
\hline 3 & $\begin{array}{l}\text { Financial statement presentation: Compliance } \\
\text { with IFRS for SMEs standard }\end{array}$ & $\begin{array}{l}\text { The presentation of } \\
\text { financial statement must } \\
\text { comply with Islamic law }\end{array}$ \\
\hline 4 & $\begin{array}{l}\text { Statement of Financial position: Information } \\
\text { to be presented are: cash, financial assets, } \\
\text { inventories, financial liabilities, trade and } \\
\text { other recieveable, investement property and } \\
\text { depreciation, intangible assets, biological } \\
\text { assets, current tax, non controlling interest } \\
\text { and provision }\end{array}$ & $\begin{array}{l}\text { Information to be } \\
\text { presented are: cash, } \\
\text { financial assets, financial } \\
\text { liabilities, and recieveable } \\
\text { assets from other party }\end{array}$ \\
\hline 5 & $\begin{array}{l}\text { Income statement and comperhensive income } \\
\text { statement: Revenue and expenses }\end{array}$ & $\begin{array}{l}\text { Income statement: } \\
\text { revenue: zakat fund, } \\
\text { expenses: zakat program } \\
\text { incluiding zakat for } \\
\text { produtive purposes }\end{array}$ \\
\hline 6 & Statement of equity & $\begin{array}{l}\text { Statement of Equity in } \\
\text { zakat for productive } \\
\text { purposes }\end{array}$ \\
\hline 7 & Statement of cash flows & $\begin{array}{l}\text { Statement of cash flows } \\
\text { in zakat for productive } \\
\text { purposes, particularly for } \\
\text { the financing activities } \\
\text { (zakat for productive } \\
\text { purposes) }\end{array}$ \\
\hline II & $\begin{array}{l}\text { Basic financial instrument: is a contract that } \\
\text { gives rise to a financial asset of one entity and } \\
\text { a financial liability or equity instrument of } \\
\text { another entity }\end{array}$ & $\begin{array}{l}\text { Statement of long term } \\
\text { loan to another entity as } \\
\text { one of the product of } \\
\text { zakat for productive } \\
\text { purposes (qardh hasan) }\end{array}$ \\
\hline 22 & Liabilities and equity: classifying the financial & Classifying the financial \\
\hline
\end{tabular}


Ifrs Based Zakat Reporting: Adoption Rational Westernmethod Into

Institutional Accountability

(Mohammad Bintang Pamuncak ${ }^{1}$, Bayu Taufiq Possumah², Zairihan Abdul Hamid ${ }^{3}$ )

assets as liabilities of equity

assets under Islamic
finance scheme (zakat for
productive purposes
product) to liabilities or
equity

23 Revenue collected from: sale of goods, Statement of revenue services, leases or construction contracts from Zakat for productive purposes under Islamic finance schemes

28 Employee benefits: all form of consideration Statement of the benefit given by an entity in exchange for service that gained by the rendered by employees, including directors employees as they are and management aamil

Source: IFRS for SMEs (2015)

Those are the standards of IFRS for SMEs that could be applicable to zakat institution. However, we only discuss the scope of IFRS for SMEs standard that quite similar to the application of zakat institution, particularly in zakat for productive purposes.

\section{c. Step by Step Transitioning Proposal to adopt The IFRS Standards}

As it was stated before, that the IFRS is issued by IASB in english, so perhaps the very first step in adopting IFRS as standard of financial reporting for zakat institution is interpreting IFRS. Therefore the IFRS be more simplified and applicable for zakat institution. Alongside with it, the law must be prepared. This is important considering one of the problem in adopting IFRS, that there is a lag between IFRS and national law.

Moreover, some countries such Indoenesia for example has already have the financial reporting standard for zakat and infaq/sadaqa which is stated in the PSAK Sharia I09. Combining the IFRS and local standard is critical so that the zakat institution can be more transparent and stakeholders can also fully support the development of zakat institution in the future, considering the argument from Alkhtani (2012) which stated that the IFRS provides useful information for decision making. This combination also will answer critics about PSAK I09 from Alim (2015) which proposed that there must be a revision on PSAK I09 particularly in the issue about zakat for productive purpose. 
Nevertheless, Based on Lestari (2015) generally the process of adopting IFRS (for example in Indonesia) is simplified by this graph below:
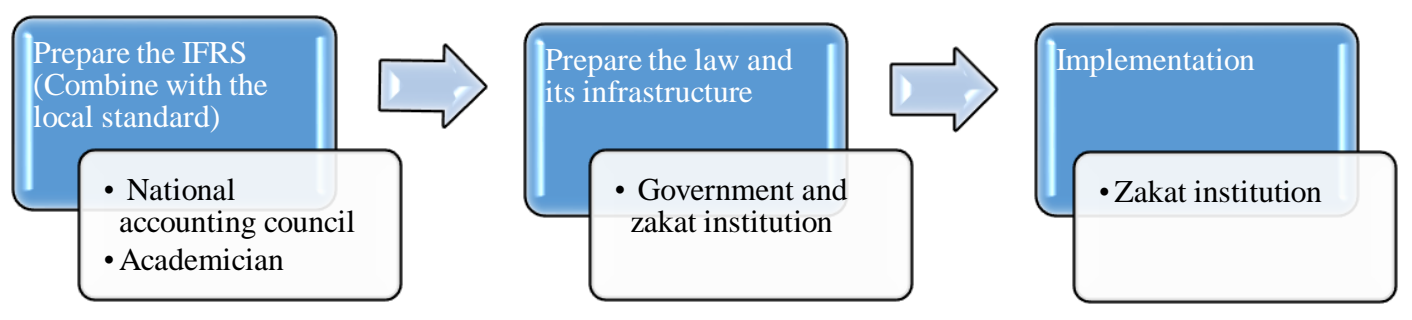

\section{Source: Lestari, (2015)}

Firstly, there must be a preparation on the supporting infrastucture and also evaluation and impact factor that would be happened after the adoption of IFRS. This phase involve an input and reccomendation from academician and this phase is organized by the National accounting council of each countries. Afterwards, the law and its infrastucture must be done by Government and also involving zakat. The application of some standard must begin in this phase. And last after all of the preparation is done, the standard can be implemented to all zakat institution (Lestari, 20I5)

\section{RESULTS AND DISCUSSION}

By incorporating insights from the theories, the preliminary analysis of logical suitability, with an in-depth understanding of the local environment we propose and discuss in this section several scenarios for the IFRS for Zakat Institution implementation. At a basic level, the main influences on the financial reporting regulations of zakat Institution

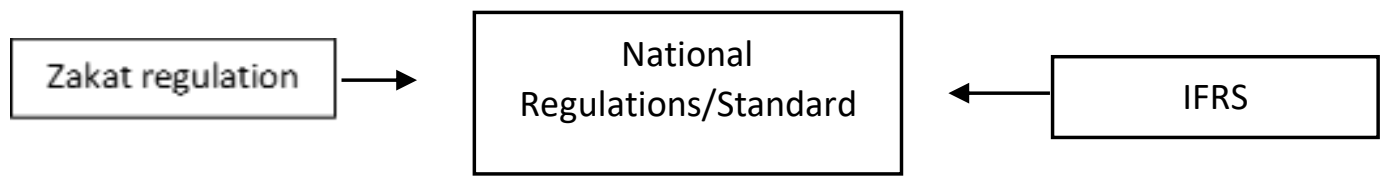

IFRS implementation is necessary for Zakat Institution for the support of global economic and finance development especially Sustainable Development Growth (SDGs), and for providing useful and comparable information (thesis). This is important, considering that without IFRS it is difficult to measure the SDGs. Reciprocally, SDGs is incomplete without IFRS. Therefore, aligning IFRS with SDGs is sine qua non (Sapovadia, 2017). Moreover, Sapovadia (2017) 
Ifrs Based Zakat Reporting: Adoption Rational Westernmethod Into

Institutional Accountability

(Mohammad Bintang Pamuncak ${ }^{1}$, Bayu Taufiq Possumah², Zairihan Abdul Hamid ${ }^{3}$ )

explains the reason why IFRS is important for SDGs. It is because, a business enterprise is established by the resource from society / government and environment, so that's why the proper financial reporting which stated the contribution that a business entreprise will give to its resource will be beneficial for all elements of the business enterprise. Moreover, it is also can make the financial report more understandable and more transparent.

Based on this argument, IFRS for Zakat Institution should be adopted and implemented. In this context, the IFRS for Zakat Institution implementation provides new opportunities for being of great interest for researchers, practitioners and regulatory bodies. Particularly the financial report that will give brief information about the contribution of zakat institution for its stakeholders.

\section{CONCLUSION}

The development of zakat institution is massive. At least it is proved by the development of zakat fund (Al Parisi, 2017) and the development of zakat program in some countries, lately known as zakat for productive purposes program (Hassan and Noor, 2015; Yuman and Clarke, No Year). However, zakat institution in Indonesia also needs an evaluation and suggestion, particularly in the term of financial reporting standard that still have fiqh issues, particularly in the reporting of zakat for productive purpose. This is important, considering that the financial reporting of zakat institution is a meausrement of good governance of the institution. Whereas the financial reporting is a measuerement of accountability and transparency of an institution. Since Alim (2015) comes up with critics about the PSAK I09 that rules the financial reporting standard for zakat infaq and saqada

Therefore, this study attempts to evaluate the characteristics of zakat institution and compare it with the characteristics of Islamic Microfinace Institution and Characteristics of Small and Medium Enterprises (SMEs) in Indonesia, so then the International Financial Reporting Standard (IFRS) which is a financial standard that accept globally can be used as a main reference for evaluating the PSAK 109 about zakat infaq and shadaqa.

Thereby, this study found that practically zakat institution is simillar to the SMEs. Since they share similar characteristics which are: Number of employees, Total net assets, Sales and Investment. (Ayyagari, et.al, 2007) Thereby, we use the IFRS for SMEs standard as a financial statement measurement.

Moreover this study also found that IFRS for SMEs consist of 35 strandard (20I5) and we propose for minimum II of them to use in Zakat institution, 
particularly zakat for prodcutive purposes. However, those II standard are related only to the financial structure of zakat institution, and not comply yet to the Islamic law. Therefore, we suggest future studies could discuss the sharia compliance in the adoption of IFRS for SMEs to zakat institution.

\section{REFERENCES}

Abdul Wahab, Norazlina., Abdul Rahman, Abdul Rahim. 20I I. "A Framework to analyse the efficiency and governance of Zakat Institutions" Journal of Islamic Accounting and Business Research, Vol. 2 Issue: I

Abdul Wahab, Norzalina, Zainol, Zairy., Abu Bakar. 2017. "Towards developing services quality inderx for zakat institutions" Journal of Islamic Accounting and Business research, Vol. 8 Issue: 3, pp 326-333

Ahmed, Habib. 2002. "Financing Microenterprises: An Analytical study of Islamic Microfinance Institution”. Islamic Economic Studies, Vol.9, No.2

AOSSG, 2015, Financial Reporting by Islamic Financial Institutions: A study of financial statements of Islamic financial institutions, Asian-Oceanian Standard-Setters Group

Al Parisi, Salman. 2017. "Overview of Forecasting Zakat Collection in Indonenesia using Multiplicative Decomposition” International Journal of Zakat 2 (I) page 45-59

Alim, Mohammad Nizarul. 2015. "Utilization and Accounting of Zakat for Productive purposes in Indonesia: A Review. Procedia-Social and Behavioral Science

Ayyagari, Meghana., Beck, Thorsten and Demrgue-Kunt, Asli. 2007. "Small and Medium Enterprises across the Globe" Small Business Economics, Vol. 29, No. 4 pp. 415-434

Budd, R.W., Thorp, R.k. \& Donohue, L. I967. Content analysis of communications, New York: The Macmillan Co

Fearnley, Setlla and Hines, Tony. 2007. "How IFRS has destabilised financial reporting for UK non-listed entities" Journal of Financial Regulatin and Compliance, Vol. I5 Issue: 4 pp.394-408

Francis, Abogaye-Otchere and Agbeibor, Juliet. 2012. "The International Financial Reporting Standard for Small and Medium Sized entities (IFRS for SMES): Suitability for Small Business in Ghana” Journal of Financial Reporting and Accounting, Vol. IO Issue: 2, pp. I90-2I4 
Ifrs Based Zakat Reporting: Adoption Rational Westernmethod Into

Institutional Accountability

(Mohammad Bintang Pamuncak ${ }^{1}$, Bayu Taufiq Possumah², Zairihan Abdul Hamid ${ }^{3}$ )

Hassan, Nuhani Md. And Noor, Abd Halim Mohd. 20I5. "Do Capital Assistance Programs by Zakat Institutions Help the poor?” Procedia Economics and Finance 3I, IFRS for SMEs, 2015

Ihsan, Hidayatul., Ayedh, Abdullah. 2015. "A Proposed Framework of Islamic Governance for Awqaf" Journal of Islamic Economics, Banking and Finance, Vol II No. 2

Immanuela, Intan. 2009. "Adopsi penuh dan Harmonisasi standar akuntasi Internasional" Jurnal Ilmiah widya warta

Kaleem, Ahmed., Ahmed, Saima. 2010. "The Quran and Poverty Alleviation: A Theoritical Model for Charity Based Islamic Microfinance Institutions (MFIs)". Nonprofit and Voluntary Sector Quarterly, Volume 39 Number 3 Published by sagepublications.com

Kerlinger, F.N. I986. Foundation of behavioral research (3 $\left.{ }^{\text {rd }} \mathrm{ed}\right)$. New York: Holt Rineheart and Winston

Lestari, Yona Octiani. 2013. "Konvergensi International Financial Reporting Standard (IFRS) dan Manajemen Laba di Indonesia" Jurnal EI Muhasabae-journal UIN Malang

Mantzari, Elizavet., Sigalas, Christos, Hines, Tony. 2017. "Adoption of International Financial Reporting Standards by Greek non-listed companies: The role of coercive and hegemonic pressures" Accounting Forum, pp. I85-205

Masca, Erna. 20I2. "Influence of Cultural Factors in Adoption of the IFRS for SMEs" Precedia Economics and Finance 3 pp.567-575

Mikail, Said Adekunle., Ahmad, Ali Jinnah Muhammad., Adenkule, Salami Saheed. 2017. "Utilisation of zakah and Waqf fund in Micro Takaful model in Malaysia: An exploratory study" ISRA International Journal of Islamic Finance, Vol.9 Issue: I, pp.100-I05

Pacter, Paul. 20I4. "A Place for the IFRS for SMEs in the United States?" Research in Accounting Regulation pp. 239-24I

Purnamasari, F., \& Darmawan, A. (20I7). Islamic Banking and Empowerment of Small Medium Enterprise. Etikonomi, I6(2), 22I-230.

Perera, Dinuja and Chand, Parmond. 20I5. "Issues in the adoption of International Financial Reporting Standard (IFRS) for Small and Medium-Sized enterprises (SMES) Advances in Accounting, incorporating Advamced in Interational Accounting 31 pp.I65-I78

Rahman, Rashidah Abdul., Dean, Faisal. 2013. "Challanges and Solutions in Islamic Microfinance" Humanomics, Vol. 29 No.4 
Saad, Ram Al Jaffri., Abdul Aziz, Norazita Marina., Sawandi, Norfaiezah. 2014. "Islamic accountability framework in the zakat funds management" International Conference on Accounting studies, ICAS, Kuala Lumpur

Sapovadia, Vrajlal K. 20I7. "Importance of Aligning IFRS with SDGs" www.papers.ssrn

Suryanto, T., Purnamasari, F., \& Kurniawan, M. (2018). Tax Revenue and Disparity: How to Improvement Income Inequality in Islamic Perspective. Asian Journal of Social Sciences and Management Studies, 5(2), 65-7I.

Uyar, Ali and Gungormus, Ali Haydar. 2013. "Perceptions and Knowledge of accounting proffesionals on IFRS for SMEs: Evidence from Turkey" Reseacth in Accounting Regulation pp.77-87

Van Wyk, H.A and Rossouw, J. 2009. "IFRS for SMEs in South Africa: a giant leap for accounting, but too big for entities in general" Meditari Accountancy Journal Research, Vol. I7 Issue: I, pp.99-II 6

Yacoob, Hisham., Petra, Saerah., Sumardi, Azimah., Nahar, Hairul Suhaimi. 2015. :Accountability through accounting and reporting lenses: Lessons from an Awqaf institution in a Southeast Asia Country" Humanomics, Vol. $3 I$ Issue: 3, pp.299-3I3.

Yumna, Aimatul and Clarke, Matthew. _ "Integrating zakat and Islamic charities with microfinance initiative in the purpose of poverty alleviation in Indonesia" ${ }^{\text {th }}$ International conference on Islamic Economics and Finance 
Ifrs Based Zakat Reporting: Adoption Rational Westernmethod Into

Institutional Accountability

(Mohammad Bintang Pamuncak ${ }^{1}$, Bayu Taufiq Possumah², Zairihan Abdul Hamid ${ }^{3}$ ) 